\title{
The importance of specific IgE antibodies in epidemiology of allergic rhinitis and asthma - the Epidemiology of Allergic Diseases in Poland (ECAP) survey: part one. Influence of allergy risk factors on concentration of specific IgE antibodies in serum
}

\author{
Andrzej Namysłowski ${ }^{1}$, Bolesław K. Samoliński ${ }^{1}$, Agnieszka Lipiec ${ }^{1}$, Wojciech Zieliński ${ }^{2}$, Adam J. Sybilski ${ }^{1}$, \\ Artur Walkiewicz ${ }^{1}$, Piotr Samel-Kowalik ${ }^{1}$, Krzysztof Samoliński ${ }^{3}$, Filip Raciborski ${ }^{1}$ \\ ${ }^{1}$ Department of Prevention of Environmental Hazards and Allergology, Medical University of Warsaw, Warsaw, Poland \\ ${ }^{2}$ Department of Econometrics and Statistics, Warsaw University of Life Sciences, Warsaw, Poland \\ ${ }^{3}$ Department of Public Health, Medical University of Warsaw, Warsaw, Poland
}

Adv Dermatol Allergol 2018; XXXV (5): 520-526 DOI: https://doi.org/10.5114/pdia.2017.70894

\begin{abstract}
Introduction: Specific immunoglobulins E (slgE) are important parameters to estimate severity of allergic diseases. Aim: To determine the influence of allergy risk factors on the concentration of specific IgE antibodies in serum. Material and methods: The concentration of slgE antibodies against allergens Dermatophagoides pteronyssinus, cat dander, timothy grass, Alternaria alternata were determined in serum of 4077 respondents randomly selected from 9 regions (ECAP study). The positive results of $\operatorname{sigE}(\geq 0.35 \mathrm{IU} / \mathrm{ml})$ were correlated to answers in questionnaires ECRHSII and ISAAC.

Results: slgE are more frequently detected in respondents declaring an allergic disease of a father than of a mother $(D$. pteronyssinus $p<0.05$, A. alternata $p<0.01$ ). An early beginning to attend school, kindergarten or nursery increases the frequency of slgE detection $(p<0.05)$. If the number of children who slept in the same room as a respondent before the respondent was five years old, was lower, slgE antibodies are more frequently detected ( $p<0.05$ ). Relating to: 1$)$ all 4 allergens, slgE are the most frequently detected in respondents declaring absence of a carpet/rug at home $(p<0.05), 2)$ cat dander - less frequently detected in respondents who have a cat at home at the age of $1-4$ years $(p<0.005)$.

Conclusions: Carpets/rugs capture a portion of mite, epidermal, mould allergens located at home, wherefore absence of a carpet or rug causes greater stimulation of an immune system by these allergens; as a consequence, IgE antibodies are the most frequently detected in respondents. Household contacts of the respondents, at the age of 1-4 years, with cats induced partial immune tolerance to cat dander.
\end{abstract}

Key words: specific immunoglobulins E, allergy, epidemiology, ECAP.

\section{Introduction}

Scientific studies accomplished within the last 20 years demonstrate that allergy and asthma are the most rapidly proliferating diseases in children's population, and affect even more than $30 \%$ of infants in developed countries. Allergy and asthma are currently diseases of affluence, a major prevalence and morbidity rate for people less than 30 years old, suffering from non-infectious chronic diseases [1-4]. Epidemiological analysis shows that inhabitants of urban areas redevelop allergies more frequently than inhabitants of rural areas [5]. In patients with allergic rhinitis, the risk of asthma is several times higher [2]. In turn, asthma significantly impacts on the quality of patients' life and may socially exclude some of them. Therefore, it is remarkably important to find risk factors for periodic rhinitis, chronic rhinitis and asthma. Numerous studies were performed as part of the Epidemiology of Allergic Diseases in Poland (ECAP) survey, proving epidemiological significance

Address for correspondence: Filip Raciborski PhD, Department of Prevention of Environmental Hazards and Allergology, Medical University of Warsaw, 1 a Banacha St, 02-091 Warsaw, Poland, phone: +48 501086 520, e-mail: filip.raciborski@gmail.com Received: 8.09.2017, accepted: 14.09.2017. 
of these diseases and great diversity of allergy risk factors [6-9]. The obtained results have evidenced, among others, meaningfully different sensitivity to common inhalation allergens, particularly comparing inhabitants of urban areas to inhabitants of villages. It was necessary to supplement results of this survey by determination of specific IgE in respondents' serum. Determination of specific IgE is the most modern and the most reliable method to evaluate allergic hypersensitivity [10, 11]. The present study is a continuation of the ECAP survey, epidemiological studies of allergy and asthma, performed in 9 regions of Poland [12].

\section{Aim}

Aim of the study was to determine the influence of allergy risk factors on the concentration of specific IgE antibodies in serum. Additionally, aims of the study described in this article were: a) to evaluate the prevalence of sensitivity to the most important inhalation allergens (Dermatophagoides pteronyssinus, cat dander, timothy grass, Alternaria alternata) in the population of Poland, b) to evaluate the influence of sensitivity to aeroallergens on the prevalence of allergic rhinitis and asthma.

\section{Material and methods}

Twenty two thousand seven hundred and three respondents were randomly selected, using their personal identity numbers, from 8 cities with a population in excess of 150000 and one rural region. The survey was based on international standards ECRHSII, using connected questionnaires ECRHSII and ISAAC [12]. Four thousand seven hundred eighty-three respondents were randomly selected and examined by allergists. Blood from 4077 respondents was collected, the concentration of IgE antibodies against allergens d1 (D. pteronyssinus), e1 (cat dander), g6 (timothy grass), m6 (A. alternata) was determined in serum, using the reference method CAP (Phadia reagents, UniCAP 100 laboratory system). The concentration of IgE antibodies of at least $0.35 \mathrm{IU} / \mathrm{ml}$ (classes 1-6) was considered positive. The IgE-determined respon- dents included 2223 females (urban - 2044, rural - 179) and 1854 males (urban -1704, rural-150). One thousand twenty six respondents (urban -924, rural -102) were aged 6-7 years, 1053 respondents (urban - 1051, rural - 102) were aged 13-14 years, and 1898 respondents (urban - 1773, rural -125) were adults. An exact methodology of the ECAP survey is described at www.ecap.pl [12] and in the Polish Journal of Allergology [13].

The results of IgE antibodies determination were correlated to answers to these questions:

- Does any other member of the family (mother, father, sibling(s), maternal grandparents, paternal grandparents) suffer from allergic diseases?

- How many times did you move house before the age of 5 years?

- What age did you first attend school, kindergarten or nursery?

- How many other children regularly slept in the same room as you before you were 5 years old? (in your family home)

- How old is the oldest carpet or rug in the room which you use most at home during the day?

- How old is the oldest carpet or rug in the room where you sleep?

- How old is your mattress?

- Has there ever been any mould or mildew on any surface inside the home?

- How much are you annoyed (on a scale between 0 and 10) by outdoor air pollution (from traffic, industry, etc.) if you keep your windows open?

- Do you keep a cat?

- Was there a cat in your home when you were a child (the first year of life, 1-4 years old, 4-15 years old)?

- What term (farm far away from the neighbours, village in the rural area, small town, suburb of a city, inner city) best describes the place you lived most of the time when you were under the age of 5 years?

- Have you ever smoked for as long as a year?

- Have you been regularly exposed to tobacco smoke in the last 12 months?

Table 1. Number (percentage) of respondents with slgE concentration $\geq 0.35 \mathrm{IU} / \mathrm{ml}$ (classes 1-6)

\begin{tabular}{|c|c|c|c|c|c|}
\hline \multirow{2}{*}{$\begin{array}{l}\text { Relatives with } \\
\text { an allergic disease }\end{array}$} & \multicolumn{5}{|c|}{ Respondents' slgE against } \\
\hline & D. pteronyssinus (d1) & Cat dander (e1) & Timothy grass (g6) & A. alternata (m6) & $N(100 \%)$ \\
\hline Mother & 47 (15.3\%) & $23(7.5 \%)$ & $44(14.3 \%)$ & $8(2.6 \%)$ & 307 \\
\hline Father & 44 (24.3\%) & 18 (9.9\%) & 31 (17.1\%) & $14(7.7 \%)$ & 181 \\
\hline Sibling(s) & $76(16.7 \%)$ & $39(8.6 \%)$ & $78(17.1 \%)$ & $15(3.3 \%)$ & 456 \\
\hline Paternal grandparents & $11(12.6 \%)$ & $2(2.3 \%)$ & $10(11.5 \%)$ & $2(2.3 \%)$ & 87 \\
\hline Maternal grandparents & $6(13.0 \%)$ & $2(4.4 \%)$ & $2(4.4 \%)$ & $1(2.2 \%)$ & 46 \\
\hline Anyone at all & $267(17.9 \%)$ & $119(8.0 \%)$ & $240(16.1 \%)$ & $72(4.8 \%)$ & 1489 \\
\hline No one & 327 (12.8\%) & $120(4.7 \%)$ & 283 (11.1\%) & 80 (3.1\%) & 2561 \\
\hline
\end{tabular}

$N$ includes respondents also declaring an allergic disease in other relative(s): mother 592, father 371, sibling(s) 720, paternal grandparents 222, maternal grandparents 122 . 
- Did your mother, father or carer smoke cigarettes when you were a child?

- Did your mother or carer smoke in the first year of your life?

The study was approved by the Institutional Bioethics Committee.

\section{Statistical analysis}

The aim of the statistical analysis was to compare proportions of people with a high level of immunoglobulin in two groups. The classical approximate test for comparison of two proportions was applied [14]. If calculated $p$-value was smaller than 0.05 , the statistically

\begin{tabular}{|c|c|c|c|c|}
\hline & & OR & Lower CL & Upper CL \\
\hline \multirow[t]{4}{*}{ Anyone at all (Table 1) } & D. pteronyssinus (d1) & 1.4925 & 1.3164 & 1.6686 \\
\hline & Cat dander (e1) & 1.7642 & 1.5021 & 2.0263 \\
\hline & Timothy grass (g6) & 1.5475 & 1.3622 & 1.7328 \\
\hline & A. alternata (m6) & 1.5807 & 1.2557 & 1.9057 \\
\hline \multirow[t]{4}{*}{$2-5$ years (Table $2 A)$} & D. pteronyssinus (d1) & 1.1381 & 0.9575 & 1.3187 \\
\hline & Cat dander (e1) & 1.7071 & 1.4168 & 1.9974 \\
\hline & Timothy grass (g6) & 1.4235 & 1.228 & 1.619 \\
\hline & A. alternata (m6) & 2.1739 & 1.7945 & 2.5533 \\
\hline \multirow[t]{4}{*}{6 years } & D. pteronyssinus (d1) & 0.9285 & 0.7364 & 1.1206 \\
\hline & Cat dander (e1) & 0.6993 & 0.3916 & 1.007 \\
\hline & Timothy grass (g6) & 0.8431 & 0.6373 & 1.0489 \\
\hline & A. alternata (m6) & 0.6009 & 0.205 & 0.9968 \\
\hline \multirow[t]{4}{*}{7 years } & D. pteronyssinus (d1) & 0.5586 & 0.1016 & 1.0156 \\
\hline & Cat dander (e1) & 0.1991 & -0.9475 & 1.3457 \\
\hline & Timothy grass (g6) & 0.4442 & -0.0872 & 0.9756 \\
\hline & A. alternata (m6) & 0.2092 & -1.1922 & 1.6106 \\
\hline \multirow[t]{3}{*}{ No children (Table 2 B) } & Cat dander (e1) & 1.287 & 1.0225 & 1.5515 \\
\hline & Timothy grass (g6) & 1.3207 & 1.1348 & 1.5066 \\
\hline & A. alternata (m6) & 1.497 & 1.1723 & 1.8217 \\
\hline \multirow[t]{3}{*}{ One child } & Cat dander (e1) & 1.0343 & 0.7701 & 1.2985 \\
\hline & Timothy grass (g6) & 0.8691 & 0.6818 & 1.0564 \\
\hline & A. alternata (m6) & 0.8606 & 0.5301 & 1.1911 \\
\hline \multirow[t]{3}{*}{ More than two children } & Cat dander (e1) & 0.5763 & 0.1672 & 0.9854 \\
\hline & Timothy grass (g6) & 0.7889 & 0.5335 & 1.0443 \\
\hline & A. alternata (m6) & 0.6071 & 0.1083 & 1.1059 \\
\hline \multirow{3}{*}{$\begin{array}{l}\text { Absence of a carpet } \\
\text { or rug (Table } 3 \mathrm{~A} \text { ) }\end{array}$} & D. pteronyssinus (d1) & 1.3924 & 1.1899 & 1.5949 \\
\hline & Cat dander (e1) & 1.4003 & 1.1019 & 1.6987 \\
\hline & A. alternata (m6) & 1.5382 & 1.1767 & 1.8997 \\
\hline \multirow{3}{*}{$\begin{array}{l}\text { Absence of a carpet } \\
\text { or rug (Table } 3 \mathrm{~B} \text { ) }\end{array}$} & D. pteronyssinus (d1) & 1.4479 & 1.2516 & 1.6442 \\
\hline & Cat dander (e1) & 1.4448 & 1.1545 & 1.7351 \\
\hline & A. alternata (m6) & 1.4774 & 1.121 & 1.8338 \\
\hline Yes (Table 4) & Cat dander (e1) & 1.4503 & 1.1288 & 1.7718 \\
\hline No cat, at least $1-4$ years & Cat dander (e1) & 1.3988 & 1.121 & 1.6766 \\
\hline
\end{tabular}

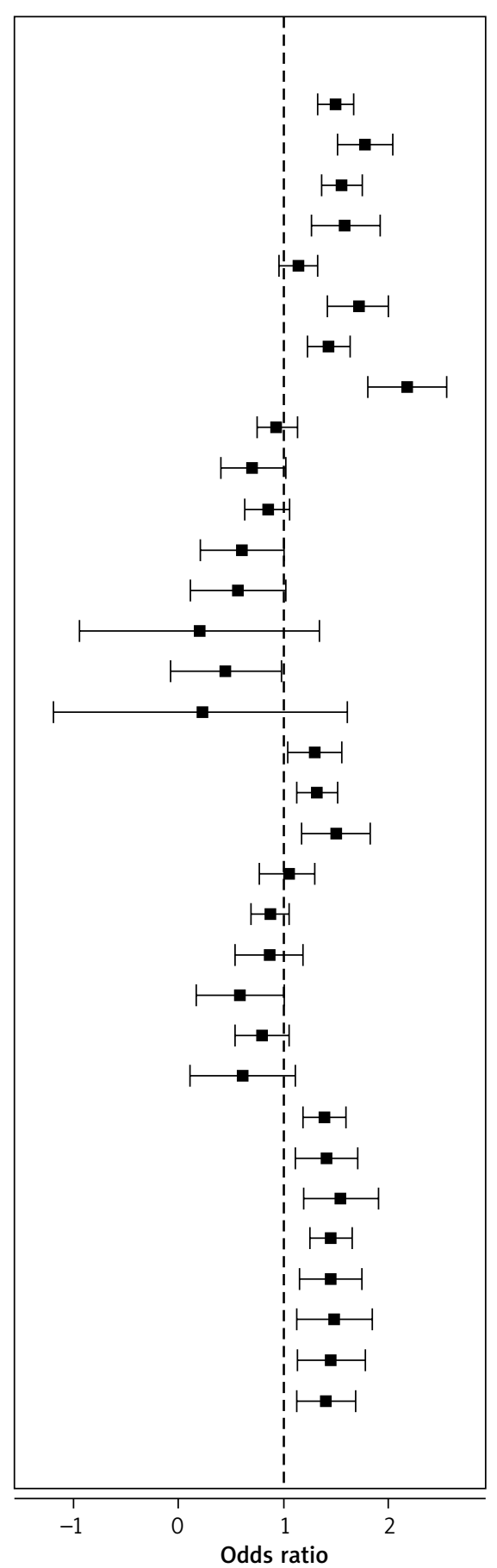

Figure 1. Influence on detection of specific IgE antibodies (classes 1-6) against Dermatophagoides pteronyssinus, cat dander, timothy grass, Alternaria alternata in respondents' serum 
significant difference between investigated proportions was recognised. Otherwise, the fractions of people with a high level of immunoglobulin in investigated groups may be treated as similar. Calculations were performed using the statistical package Statistica (Statistica, Tulsa, Oklahoma, US).

\section{Results}

IgE antibodies are more frequently detected in respondents declaring an allergic disease of immediate relatives ( $D$. pteronyssinus $p<0.001$, cat dander $p<$ 0.001 , timothy grass $p<0.001$, A. alternata $p<0.01$ ), the allergic disease of a father is of considerable importance ("allergic disease of a father" versus "allergic disease of a mother": D. pteronyssinus $p<0.05$, A. alternata $p<$ 0.01) (Table 1, Figure 1). There was no statistically significant difference between influence of the allergic disease of maternal grandparents and influence of the allergic disease of paternal grandparents.

An early beginning to attend school, kindergarten or nursery increases frequency of IgE antibodies detection in respondents (Table 2 , Figure 1 ). Relating to all allergens, numerous statistically significant differences were identified ( $p<0.05$ to $p<0.001$ ), comparing groups aged $2-5$ years to a group aged 6 years, groups aged $2-5$ years to a group aged 7 years, and a group aged 6 years to a group aged 7 years.

Table 2. Number (percentage) of respondents with slgE concentration $\geq 0.35 \mathrm{IU} / \mathrm{ml}$ (classes 1-6). A - Age of first attending school, kindergarten or nursery, $\mathbf{B}$ - number of other children who regularly slept in the same room as a respondent before the respondent was 5 years old

\begin{tabular}{lccccc}
\hline Variable & \multicolumn{5}{c}{ Respondents' slgE against } \\
\cline { 2 - 6 } & D. pteronyssinus (d1) & Cat dander (e1) & Timothy grass (g6) & A. alternata (m6) & N (100\%) \\
\hline A & & & & & \\
\hline year & $24(17.9 \%)$ & $7(5.2 \%)$ & $12(9.0 \%)$ & $13(5.1 \%)$ & 256 \\
\hline 2 years & $45(17.6 \%)$ & $16(6.3 \%)$ & $32(12.5 \%)$ & $50(4.7 \%)$ & 134 \\
\hline 3 years & $154(14.4 \%)$ & $69(6.4 \%)$ & $153(14.3 \%)$ & $34(5.4 \%)$ & 630 \\
\hline 4 years & $90(14.3 \%)$ & $51(8.1 \%)$ & $94(14.9 \%)$ & $19(4.0 \%)$ & 477 \\
\hline 5 years & $82(17.2 \%)$ & $33(6.9 \%)$ & $72(15.1 \%)$ & $2(0.9 \%)$ & 1225 \\
\hline 6 years & $171(14.0 \%)$ & $56(4.6 \%)$ & $142(11.6 \%)$ & & 235 \\
\hline 7 years & $21(8.9 \%)$ & $3(1.3 \%)$ & $15(6.4 \%)$ & $73(4.7 \%)$ & 1560 \\
\hline B & & & & $61(3.5 \%)$ & 1762 \\
\hline 0 & $223(14.3 \%)$ & $105(6.7 \%)$ & $231(14.8 \%)$ & $18(2.5 \%)$ & 722 \\
\hline 1 & $259(14.7 \%)$ & $105(6.0 \%)$ & $211(12.0 \%)$ & & \\
\hline $2+$ & $109(15.1 \%)$ & $27(3.7 \%)$ & $78(10.8 \%)$ & & \\
\hline
\end{tabular}

Table 3. Number (percentage) of respondents with slgE concentration $\geq 0.35 \mathrm{IU} / \mathrm{ml}$ (classes $1-6)$. A - How old is the oldest carpet or rug in the room which a respondent uses most at home during the day, $\mathbf{B}$ - how old is the oldest carpet or rug in the room where a respondent sleeps

\begin{tabular}{|c|c|c|c|c|}
\hline \multirow[t]{2}{*}{ Variable } & \multicolumn{4}{|c|}{ Respondents' slgE against } \\
\hline & D. pteronyssinus (d1) & Cat dander (e1) & A. alternata (m6) & $N(100 \%)$ \\
\hline \multicolumn{5}{|l|}{ A } \\
\hline Absence of a carpet or rug & $152(18.2 \%)$ & $63(7.5 \%)$ & $43(5.2 \%)$ & 835 \\
\hline Less than 1 year & $45(13.4 \%)$ & $11(3.3 \%)$ & $16(4.8 \%)$ & 337 \\
\hline $1-5$ years & $193(13.1 \%)$ & $85(5.8 \%)$ & $50(3.4 \%)$ & 1470 \\
\hline More than 5 years & $203(14.6 \%)$ & $80(5.7 \%)$ & $43(3.1 \%)$ & 1394 \\
\hline \multicolumn{5}{|l|}{ B } \\
\hline Absence of a carpet or rug & $168(18.6 \%)$ & $69(7.6 \%)$ & $45(5.0 \%)$ & 905 \\
\hline Less than 1 year & $43(12.4 \%)$ & $13(3.8 \%)$ & $15(4.3 \%)$ & 346 \\
\hline $1-5$ years & $203(13.6 \%)$ & $91(6.1 \%)$ & $53(3.6 \%)$ & 1493 \\
\hline More than 5 years & $180(13.9 \%)$ & $65(5.0 \%)$ & 39 (3.0\%) & 905 \\
\hline
\end{tabular}


Table 4. Number (percentage) of respondents with slgE concentration $\geq 0.35 \mathrm{IU} / \mathrm{ml}$ (classes 1-6). A - Respondent keeps a cat, $\mathbf{B}$ - age of a respondent when a cat was at home (the first year of life, 1-4 years, 4-15 years)

\begin{tabular}{lcc}
\hline Variable & Cat dander $(\mathrm{e} 1)$ & $N(100 \%)$ \\
\hline A & $51(7.8 \%)$ & 653 \\
\hline Yes & $188(5.5 \%)$ & 3403 \\
\hline No & & \\
\hline Never & $183(6.3 \%)$ & 2924 \\
\hline First year of life & $3(2.5 \%)$ & 121 \\
\hline $0-4$ years & $5(11.4 \%)$ & 44 \\
\hline 0-15 years & $8(3.1 \%)$ & 255 \\
\hline $1-4$ years & $6(3.2 \%)$ & 187 \\
\hline $1-15$ years & $2(1.5 \%)$ & 130 \\
\hline 4-15 years & $31(7.9 \%)$ & 395 \\
\hline
\end{tabular}

If the number of other children, who regularly slept in the same room as a respondent before the respondent was 5 years old, is lower, IgE antibodies are more frequently detected in respondents (Table 2, Figure 1). Relating to allergens of cat dander, timothy grass, and A. alternata, numerous statistically significant differences were identified ( $p<0.05$ to $p<0.005)$, comparing groups $0,1,2+$, especially group " 0 " to " $2+$ ".

Relating to allergens of $D$. pteronyssinus, cat dander, and $A$. alternata, IgE antibodies are the most frequently detected in respondents declaring absence of a carpet or rug in the room which the respondent uses most at home during the day or in the room where the respondent sleeps (Table 3, Figure 1). Numerous statistically significant differences were identified ( $p<0.05$ to $p=$ $0.001)$, comparing a group "absence of a carpet or rug" to every remaining group. Very similar values were obtained after excluding, from the statistical analysis, respondents declaring they have ever had asthma. Thus, the observed relationship does not result from asthmatics conforming to doctor's orders, and removing carpets and rugs from home.

Relating to an allergen of cat dander, IgE antibodies are more frequently detected in respondents keeping a cat $(p<0.05)$, but less frequently detected in respondents declaring there was a cat at home when they were aged 1-4 years ("cat at home, at least, when respondents were aged 1-4 years" versus "no cat at home when respondents were aged 1-4 years" $p<0.005$ ) (Table 4, Figure 1).

IgE antibodies are more frequently detected in respondents living in a city, most of the time when they were under the age of 5 years ("rural" versus "urban": cat dander $p<0.001$, timothy grass $p<0.001$, A. alternata $p<0.001$ ) (Table 5, Figure 1).

\section{Discussion}

Numerous studies were performed as part of the ECAP survey, proving epidemiological significance of these diseases and great diversity of allergy risk factors. It was necessary to supplement results of this survey by determination of specific IgE in respondents' serum. The aim of the study described in this article was to determine influence of allergy risk factors on the concentration of specific lgE antibodies in serum.

IgE antibodies are more frequently detected in respondents declaring an allergic disease of a father than in respondents declaring an allergic disease of a mother. This results, probably, from immune tolerance to some of potential allergens, as a consequence of interaction with the allergic mother's immune system, in the course of a foetal period. In a study by Hensley Alford et al., father's allergic disease history, particularly asthma history, was more strongly related to paediatric outcomes than mother's history [15]; in a study by Anderson et al., a history of paternal asthma, and to some degree allergy, appears to confer an increased risk of allergic sensitization in preschool children, similar maternal histories are not significantly associated with these developments [16]. On the other hand, in a study by Mandhane et al., maternal atopy but not paternal atopy was significantly associated with asthma of male children [17], while in a meta-analysis by Lim et al., maternal asthma increases the offspring disease risk to a greater extent than paternal disease [18]. Moreover, in a study by Arshad et al., maternal asthma was associated with asthma in girls but not in boys, whereas paternal asthma was associated with asthma in boys but not in girls [19]. In a study by Westman et al., parental allergy-related disease may be an important risk factor for nonallergic rhinitis as well as allergic rhinitis, and the risk is comparable for maternal and paternal allergy [20]. In a study by Fuertes et al., parental allergic diseases both pose risks to childhood

Table 5. Number (percentage) of respondents with slgE concentration $\geq 0.35 \mathrm{IU} / \mathrm{ml}$ (classes 1-6). Relating to the place where a respondent, aged less than 5 years, lived most of the time

\begin{tabular}{lccccc}
\hline Place & \multicolumn{4}{c}{ Respondents' slgE against } \\
\cline { 2 - 5 } & D. pteronyssinus (d1) & Cat dander (e1) & Timothy grass (g6) & A. alternata (m6) & N (100\%) \\
\hline Rural & $99(13.3 \%)$ & $21(2.8 \%)$ & $53(7.1 \%)$ & $10(1.4 \%)$ & 743 \\
\hline Urban & $494(14.9 \%)$ & $218(6.6 \%)$ & $470(14.2 \%)$ & $142(4.3 \%)$ & 3310 \\
\hline
\end{tabular}


allergic disease in the offspring, especially for asthma [21]. An early beginning to attend school, kindergarten or nursery increases the frequency of IgE antibodies detection in respondents. This results, most likely, from a greater diversity of allergens, which more strongly stimulates an immune system to allergic reactions, in humans exposed to these allergens in the first year of their life. The school environment can be an important size of exposure to indoor allergens detected in settled school dust [22]. In a study by Sporik et al., exposure in early childhood to house dust mite allergens is an important determinant of the subsequent development of asthma [23], while in a study by Cole Johnson et al., dust mite exposure in early childhood is associated with a higher risk of sensitization in the presence of a positive parental history of atopic disease [24], in infants and preschool children. Authors of ARIA 2010 suggest multifaceted interventions to reduce early life exposure to house dust mite [25]. On the other hand, regular sleeping in the same room as other children, before a respondent was 5 years old, decreases the frequency of IgE antibodies detection in respondents. The co-sleeping leads to more frequent infections, which presumably decreases probability of prospective allergic reactions. Numerous studies prove that a higher number of siblings protects against the development of allergy and asthma [26]. Carpets and rugs capture a portion of mite, epidermal, mould allergens located at home, wherefore absence of a carpet or rug causes greater stimulation of an immune system by these allergens; as a consequence, IgE antibodies are the most frequently detected in respondents. House dust mite exposure is dose-dependently related to a higher risk of sensitization to mites [27]. IgE antibodies against cat dander are more frequently detected in respondents keeping a cat, nonetheless household contacts of the respondents, at the age of 1 to 4 years, with cats induced partial immune tolerance to this allergen. Celedon et al. showed that in children who did not have a maternal history of asthma, exposure to Fel $d 1$ cat antigen at the age of 2 to 3 months was associated with a reduced risk of wheezing, but in children with a maternal history of asthma, similar exposure was associated with an increased risk of wheezing, and the risk associated with cat exposure became greater with increasing duration of follow-up [28]. In infants and preschool children, authors of ARIA 2010 suggest no special avoidance of exposure to pets at home [25].

\section{Conclusions}

IgE antibodies are more frequently detected in respondents declaring an allergic disease of a father than in respondents declaring an allergic disease of a mother. An early beginning to attend school, kindergarten or nursery increases frequency of IgE antibodies detection in respondents. Regular sleeping in the same room as other children, before a respondent was 5 years old, decreases frequency of IgE antibodies detection in respondents. Carpets and rugs capture a portion of mite, epidermal, mould allergens located at home, wherefore absence of a carpet or rug causes greater stimulation of an immune system by these allergens; as a consequence, IgE antibodies are the most frequently detected in respondents. IgE antibodies against cat dander are more frequently detected in respondents keeping a cat, nonetheless household contacts of the respondents, at the age of 1 to 4 years, with cats induced partial immune tolerance to this allergen.

\section{Acknowledgments}

The study was performed as part of research grant from the National Science Centre (Poland), 2011/01/B/ NZ7/05289.

\section{Conflict of interest}

The authors declare no conflict of interest.

\section{References}

1. European Allergy White Paper, The UCB Institute of Allergy. Allergic diseases as a public health problem in Europe. UCB Institute of Allergy. Brussels, Belgium 1997.

2. Leynaert B, Neukirch C, Kony S, et al. Association between asthma and rhinitis according to atopic sensitization in a population-based study. J Allergy Clin Immunol 2004; 113: 86-93.

3. Bousquet J, Schünemann HJ, Samolinski B, et al. Allergic rhinitis and its impact on asthma (ARIA): achievements in 10 years and future needs. J Allergy Clin Immunol 2012; 130: 1049-62.

4. Van Cauwenberge P, Watelet JB, Van Zele T, et al. Spreading excellence in allergy and asthma: the Gallen Project. Allergy 2005; 60: 858-64.

5. Samoliński B, Tomaszewska A, Raciborski F. Różnice występowania alergii i astmy w środowisku wiejskim i miejskim w Polsce - badanie ECAP. Medycyna Środowiskowa 2008; 11: 1-7.

6. Samoliński B, Sybilski A, Raciborski F, et al. Występowanie astmy oskrzelowej u dzieci, młodzieży i młodych dorosłych w Polsce w świetle badania ECAP. Alergia Astma Immunologia 2009; 14: 27-34.

7. Samoliński B, Sybilski AJ, Raciborski F, et al. Prevalence of rhinitis in Polish population according to the ECAP (Epidemiology of Allergic Disorders in Poland) study. Otolaryngol Pol 2009; 63: 324-30.

8. Stankiewicz-Choroszucha B, Wawrzyniak Z, Lipiec A, et al. Consequences of smoke inhalation in the "Epidemiology of Allergic Diseases in Poland” project (ECAP). Ann Agric Environ Med 2011; 18: 420-8.

9. Sybilski AJ, Raciborski F, Lipiec A, et al. Atopic dermatitis is a serious health problem in Poland. Epidemiology studies based on the ECAP study. Postep Derm Alergol 2015; 32: 1-10. 
10. Eriksson NE. Allergy screening with Phadiatop and CAP Phadiatop in combination with a questionnaire in adults with asthma and rhinitis. Allergy 1990; 45: 285-92.

11. Bousquet J, Khaltaev N, Cruz AA, et al. Allergic rhinitis and its impact on asthma (ARIA) 2008 update (in collaboration with the World Health Organization, GA(2)LEN and AllerGen). Allergy 2008; 63 Suppl 86: 8-160.

12. Available at: www.ecap.pl (Access 28.07.2016).

13. Samoliński B, Raciborski F, Lipiec A, et al. Epidemiologia chorób alergicznych w Polsce (ECAP). Alergologia Polska Pol J Allergol 2014; 1: 10-18.

14. Zieliński W. Wybrane testy statystyczne. Fundacja Rozwój SGGW. Warsaw, Poland 1999.

15. Hensley Alford S, Zoratti E, Peterson EL, et al. Parental history of atopic disease: disease pattern and risk of pediatric atopy in offspring. J Allergy Clin Immunol 2004; 114: 1046-50.

16. Anderson EL, Evans MD, DaSilva DFG, et al. History of parental allergy and asthma as predictors of allergic sensitization in their offspring. J Allergy Clin Immunol 2006; 117: S155.

17. Mandhane PJ, Greene JM, Sears MR. Sex differences in effects of breastfeeding on asthma and allergy in relation to parental atopy. J Allergy Clin Immunol 2006; 117: S198.

18. Lim RH, Kobzik L, Dahl M. Risk for asthma in offspring of asthmatic mothers versus fathers: a meta-analysis. PLoS One 2010; 5: e10134.

19. Arshad SH, Karmaus W, Raza A, et al. The effect of parental allergy on childhood allergic diseases depends on the sex of the child. J Allergy Clin Immunol 2012; 130: 427-34.

20. Westman M, Kull I, Lind T, et al. The link between parental allergy and offspring allergic and nonallergic rhinitis. Allergy 2013; 68: 1571-8

21. Fuertes E, Standl M, von Berg A, et al. Parental allergic disease before and after child birth poses similar risk for childhood allergies. Allergy 2015; 70: 873-6.

22. Tranter DC. Indoor allergens in settled school dust: a review of findings. Clin Exp Allergy 2005; 35: 126-36.

23. Sporik R, Holgate ST, Platts-Mills TAE, Cogswell JJ. Exposure to house-dust mite allergen (Der p I) and the development of asthma in childhood. N Eng J Med 1990; 323: 502-7.

24. Cole Johnson C, Ownby DR, Havstad SL, Peterson EL. Family history, dust mite exposure in early childhood, and risk for pediatric atopy and asthma. J Allergy Clin Immunol 2004; 114: 105-10.

25. Brożek JL, Bousquet J, Baena-Cagnani CE, et al. Allergic rhinitis and its impact on asthma (ARIA) guidelines: 2010 Revision. J Allergy Clin Immunol 2010; 126: 466-76.

26. Botezan C, Karamaus W. Does a higher number of siblings protect against the development of allergy and asthma? A review. J Epidemiol Commun Health 2002; 56: 209-17.

27. Institute-of-Medicine. Indoor Biologic Exposures. In: Clearing the Air. Asthma and Indoor Air Exposures. National Academy Press. Washington, DC 2000.

28. Celedon JC, Litonjua AA, Ryan L, et al. Exposure to cat allergen, maternal history of asthma, and wheezing in first 5 years of life. Lancet 2002; 360: 781-2. 